\title{
Influence of Extrusion-Cooking Conditions on Corn Pasta Quality
}

\author{
Nazeer El-Bialee, AbdelGawad M. Saad, Mohamed I. El-Didamony and Gamal Zahran
}

\begin{abstract}
Gluten free products remain the cornerstone for celiac patients. Insufficiency, poverty and little offered about gluten free products (quality and quantity) represented a high obstacle for Egyptian celiac patients. Therefore, the purpose of this research is to modify a single screw extruder to produce gluten-free pasta (GFP) (tagliatelle type). The GFP was made from corn flour under screw rotation speed $(\mathrm{N})$ of 10,25 and $50 \mathrm{rpm}$ at $40,65,90$ and $115{ }^{\circ} \mathrm{C}$ of barrel temperature (BT). Extruder performance was evaluated as specific mechanical energy (SME) and expansion ratio (Er). The cooking quality of GFP as optimum cooking time (OCT), cooked yield (CY), swelling (Sw), cooking losses (CL) and sensory characteristics (appearance, colour, taste, mouth feel and overall acceptability) were evaluated. The better results of the GFP sensory evaluation were obtained at $\mathrm{BT}=80^{\circ} \mathrm{C}, \mathrm{N}=25 \mathrm{rpm}$ and $\mathrm{Er} \approx 1.38$ with $\mathrm{OCT} \approx 3.3 \mathrm{~min}, \mathrm{CY}=196 \%, \mathrm{Sw}=210 \%$ and $C L=16.3 \%$. All parameters were given a direct proportion with processing variables $\mathrm{N}$ and BT, except CL. Furthermore, it can be predicted cooking properties values for GFP by SME value using the following equation; $\mathrm{SME} \approx 1.8675(\mathrm{Er})+\mathbf{0 . 8 0 3 7}$ $\approx 0.0608(\mathrm{OCT})^{1.5984} \approx 8 \times 10^{-17}(\mathrm{CY})^{6.7878} \approx 2 \times 10^{-9}(\mathrm{Sw})^{3.494} \approx-$ $0.0306(C L)+0.7877$.
\end{abstract}

Index Terms-Extruder Performance; Gluten Free Pasta; Corn Flour; Pasta Quality.

\section{INTRODUCTION}

The noodles were known as early as 300 B.C by Chinese [1]. However, noodle image was drawn first on the walls Egyptian tombs. Pasta is considered a type of noodle, and defined as an extruded product with consecutive drying of dough made from durum wheat semolina and water [2]. They are widely consumed throughout the world, and play an important role in human nutrition, due to its convenience (easy to cook, store and handle), palatability and low cost. Egypt occupies rank $17^{\text {th }}$ and $7^{\text {th }}$ in pasta export with 72,13 Mg.year ${ }^{-1} \approx 63,269,379 €$, and production with up to 400 Gg.year ${ }^{-1}$ [3].

Gluten-free diet (eliminate all food products containing gluten: wheat, rye and barley) require as a therapy to prevent celiac disease [4],[5]. Celiac patients (CP) or suffers chronic entheropathy is produced by gluten intolerance (prolamines

Published on March 22, 2017

N. El-Bialee, Biological Engineering Dept. Agricultural Engineering Research Institute (AEnRI), Agricultural Research Center (ARC), 12311, Dokki, Giza, Egypt (e-mail: phdzizo1@yahoo.com).

A. M. Saad, Biological Engineering Dept. Agricultural Engineering Research Institute (AEnRI), Agricultural Research Center (ARC), 12311, Dokki, Giza, Egypt (e-mail: en_gawad2000@yahoo.com).

M. I. El-Didamony, Agricultural Engineering Dept. Faculty of Agriculture, Tanta University, Egypt. (e-mail: eldidamony@agr.tanta.edu.eg).

G. Zahran Bread and Pastries Research Dept., Food Technology Research Institute, Agriculture Research Center, Giza, Egypt (e-mail: Gamalzahran32@yahoo.com ). protein), which causes atrophy of intestinal villi, malabsorption and clinical symptoms [6].

On the other hand, corn is recommended as a safe food for CP. It contains 7-13 g/100 g of proteins, very low fats, phenolics, ferulic acid, flavonoid, carotenoid, rich in dietary fibre, vitamin B6 and magnesium [7], [8]. Thus, pasta production could be used other starchy raw materials to produce GFP to suit CP such as; corn, rice, sorghum, oats, and leguminous seeds [9]-[11]. Besides sweet potato, and the combination of amaranth flour with cassava starch can make GFP [12], [13].

Extrusion cooking technology has been widely used in cereal processing like snacks, baby foods, breakfast cereals, noodle and pasta [14], [15]. There are many advantages of extrusion cooking such as versatility, low costs, high production yields, good quality products, no effluents, reduce microbial contamination and inactivate enzymes [16]. The extrusion cooking process includes mechanical and thermal treatment of material under high pressure and high temperature. Workspace for single screw extruder is divided into three areas: dosing, mixing and compression. Screw used to move the material through barrel with significant increase in temperature and pressure occurs, makes the material plasticized and taking the form of precooked viscous dough. High temperature generated during the extrusion cooking process is due to heat energy along the screw as a shearing effect, energy used for increased pressure of the viscous dough, the kinetic energy generated in the space between a screw and a barrel, also, the energy created during physiochemical changes of processed materials dependently on residence time distribution inside barrel [17], [5]. However, Low shear extruders with smooth barrels, deep flights and low screw speeds are used for product pastas, meats and cereals [18]. Raw material characteristics and operational conditions of the extruder are the main factors influencing extruded product characteristics. The main characteristics of the raw material as material type, $\mathrm{pH}$, moisture content, physical state, and chemical composition (quantity and type of starch, proteins, fats and sugars). Temperature, pressure, die diameter, shear force, as well as, screw geometry and rotation speed are the main operational condition of extrusion machine [19]. Therefore, this paper aims to modify extrusion machine to produce GFP from corn flour with high quality specifications at optimum operating conditions.

\section{MATERIALS AND METHODS}

\section{A. Extruder}

All experiments were carried out in Bread and Pastries Research Dept., Food Technology Research Institute, Agriculture Research Center, Giza, Egypt. Semi- 
commercial laboratory extruder (DEMACO) was used to extrude GFP after modification by adding heating system. Extruder was equipped with single screw length $400 \mathrm{~mm}$, a $45 \mathrm{~mm}$ of diameter, 8.9: 1 of length-diameter ratio, $8 \mathrm{~mm}$ of screw-channel depth, $29 \mathrm{~mm}$ of the screw-channel width, 5 $\mathrm{mm}$ of axial flight land width, $1 \mathrm{~mm}$ of clearance between screw and barrel, and $34 \mathrm{~mm}$ of screw pitch.

The GFP was designed as a tagliatelle type (6.5 to $10 \mathrm{~mm}$ of width) and shaped by copper circle die head with 250 and $40 \mathrm{~mm}$ of diameter and thickness. Die head has two faces; one opposite the screw with 8 circular holes $(20 \mathrm{~mm}$ of diameter) and the other face with 24 elliptic holes (product out face).

Heating system includes switcher (on/off), indicator lamp, thermostat and heater. Four heating units were connected together in parallel form to consist a heater. They made from Nichrome alloy (20\% nickel, $25 \%$ chromium) wire, rolls on rectangular of mica core $(67 \times 10 \mathrm{~mm}$.). Heating units were put in a jacket of stainless steel sheet $(0.5 \mathrm{~mm}$ of thickness $)$ and fixed on the outer wall of barrel (Fig. 1).

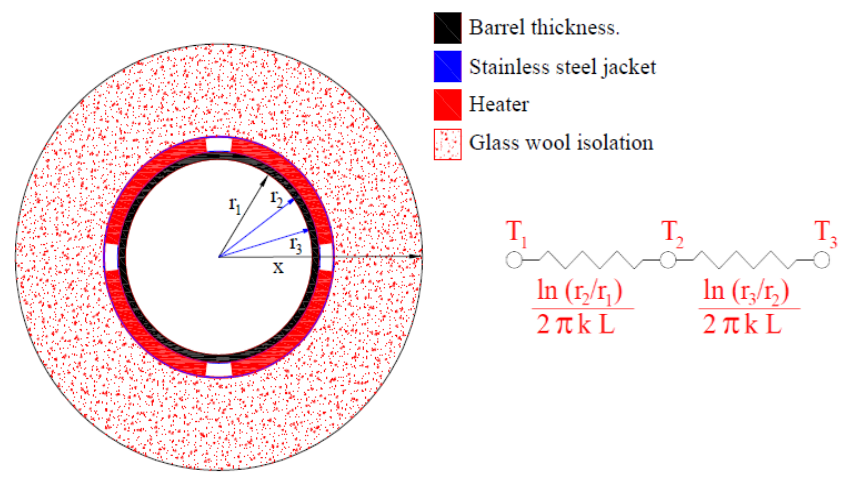

Fig.1. One - dimensional heat flow through multiple cylindrical sections and electrical analog.

Heater must be able to raise dough temperature into barrel over $200{ }^{\circ} \mathrm{C}$. So, according Fourier's law (Fig .1) $\mathrm{T}_{3}=\mathrm{T}_{1}+\left[\frac{\mathrm{m}^{*}\left(1.675+0.025+\mathrm{D}_{m c}\right)\left(\mathrm{T}_{2}-\mathrm{T}_{1}\right)}{2 \pi \mathrm{k}_{1} \mathrm{~L}}\left(\ln \frac{\mathrm{r}_{2}}{\mathrm{r}_{1}}+\ln \frac{\mathrm{r}_{3}}{\mathrm{r}_{2}}\right)\right]$, where, $\mathrm{T}_{3}$ is heater temperature $\left({ }^{\circ} \mathrm{C}\right), \mathrm{T}_{1}$ is a dough temperature $\approx 25{ }^{\circ} \mathrm{C}$ (measured), $\mathrm{m}^{*}$ is a maximum of extrusion rate $\approx 0.004 \mathrm{~kg} \mathrm{~s}^{-1}$ (calculated), $\mathrm{D}_{\mathrm{mc}}$ is a dough water content $\approx 34 \%$ [17], $\mathrm{T}_{2}$ is a maximum dough temperature (Assuming $200{ }^{\circ} \mathrm{C}$ ), $\quad \mathrm{k}_{1}$ is a stainless steel thermal conductivity $\left(19 \mathrm{~W} \mathrm{~m}^{-1}{ }^{\circ} \mathrm{C}^{-1}\right), \mathrm{L}$ is barrel length $(0.27 \mathrm{~m}), \mathrm{r}_{2}$ is outer barrel radius $(45.5 \mathrm{~mm}), \mathrm{r}_{1}$ is inner barrel radius $(42.5 \mathrm{~mm})$, and $r_{3}$ is radius of stainless steel jacket opposite of heater $(46 \mathrm{~mm})$. Hence, $\mathrm{T}_{3} \approx 257.37^{\circ} \mathrm{C}$

Coil wire length $\left(\mathrm{L}_{\mathrm{C}}\right)$ and coils $\mathrm{No}$. $(\mathrm{n})$ at $1 \mathrm{~mm}$ coil wire diameter were expressed by,

$$
\mathrm{L}_{\mathrm{C}}=\frac{\mathrm{Xq}}{\pi \mathrm{dk}_{2}\left(\mathrm{~T}_{3}-\mathrm{T}_{\mathrm{i}}\right)} \text { and } \boldsymbol{n}=\frac{\mathbf{L}_{\mathrm{C}}}{\boldsymbol{C}_{\mathrm{MC}}} \text {. }
$$

Where, $\mathrm{X}$ is heater length, $\mathrm{d}$ is the cross section diameter of coil wire $(0.001 \mathrm{~m}), \mathrm{K}_{2}$ is Nichrome thermal conductivity $\left(17 \mathrm{~W} \mathrm{~m}^{-1}{ }^{\circ} \mathrm{C}^{-1}\right), \mathrm{T}_{\mathrm{i}}$ is ambient temperature $\left(25^{\circ} \mathrm{C}\right), \mathrm{n}$ is coils No., and $\mathrm{C}_{\mathrm{MC}}$ is Mica core circumference $(0.156 \mathrm{~m})$. Hence, $\mathrm{L}_{\mathrm{C}} \approx 30.81 \mathrm{~m}$, and $\mathrm{n} \approx 245$. Meanwhile, the critical radius value of isolation for heaters emerged by,

$$
\mathbf{x}=\frac{\mathbf{k}_{3}}{\mathbf{h}}-\mathbf{r}_{2} \text {. }
$$

Where, $\mathrm{x}$ is the critical radius value of isolation $(\mathrm{m}), \mathrm{k}_{3}$ is a glass wool thermal conductivity $\left(0.038 \mathrm{~W} \mathrm{~m}^{-1}{ }^{\circ} \mathrm{C}^{-1}\right), \mathrm{h}$ is convection heat-transfer coefficient between glass wool and air $\left(6.5 \mathrm{~W} \mathrm{~m}^{-2}{ }^{\circ} \mathrm{C}^{-1}\right)$. Hence, $\mathrm{x} \approx 4 \mathrm{~cm}$. On the other hand, infrared thermometer (AG-42D model) with range -30 to $+100{ }^{\circ} \mathrm{C}$ and $\pm 0.5{ }^{\circ} \mathrm{C}$ accuracy was used to calibrate thermostat scale with inner wall barrel temperature. The relation between thermostat scale and inner wall temperature of barrel (BT) was illustrated in Fig. 2.

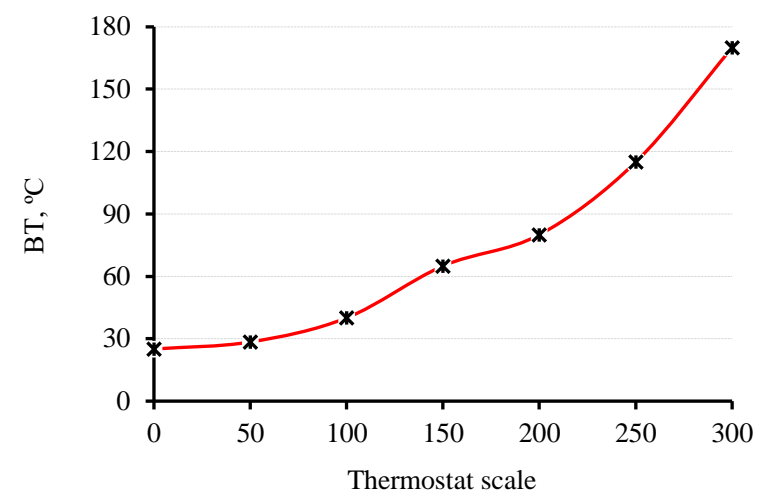

Fig.2. Relationship between thermostat scale and average inner wall temperature of barrel (BT).

\section{B. Raw materials}

Both of yellow corn flour and corn starch were obtained from El-Masreya El-Italy Co., of corn products, and Egyptian starch and glucose Co., Egypt. Meanwhile, monodiglycerides and sodium chloride were purchased from ElGomhoreia Co., Cairo, Egypt.

C. Preparation of $G F P$

The GFP was prepared from a mixture of yellow corn flour $33 \%$, corn starch $60 \%$, corn oil $4 \%$, mono-diglycerides $2 \%$ and Nacl $1 \%$. The mixture was mixed by two stainless steel rotating augers at constant speed $75 \mathrm{rpm}$ for $5 \mathrm{~min}$. Hot distilled water $\left(90^{\circ} \mathrm{C}\right)$ was added stepwise and slowly to the mixture with constant agitation for $8 \mathrm{~min}$ to obtain the optimum consistency of dough. Thereafter, the trap door was opened and dough passed through the extruder.

The noodle was dried in an air drying oven (DHG-9140A, Shanghai Sanfa Scientific Instruments Co., LTD., China) at $100{ }^{\circ} \mathrm{C}$ for $15 \mathrm{~min}$ until a final moisture of $11 \%(\mathrm{w} / \mathrm{w})$. And then, samples were cooled to room temperature.

\section{Extruder performance}

The extrusion was performed at a screw speed $(\mathrm{N})$ of 10 , 25 and $50 \mathrm{rpm}$, with $40,65,90$ and $115^{\circ} \mathrm{C}$ for inner wall temperature of barrel (BT). Data of GFP characteristics were analysed for each experiment using analysis of variance and the derived least significant difference. Extrusion rate $(\mathrm{Er})$ and power requirement $(\mathrm{Pr})$ at different conditions were measured for each sample. Product outputs were collected after $10 \mathrm{~min}$ of regular production to estimate Er. Whilst, super clamp meter-300k was used for measuring the current strength for extruder with and without load. Specific mechanical energy (SME) values were measured by

$$
\mathrm{SME}=\frac{\sqrt{3} \times V \times \cos \theta \times \eta}{1000} \times \frac{\left(\mathrm{I}_{2}-\mathrm{I}_{1}\right)}{\mathrm{Er}} .
$$

Where, $\sqrt{3}$ is resultant three phase current coefficient, $\mathrm{V}$ is a potential difference voltage $(\approx 380 \mathrm{~V}), \operatorname{Cos} \theta$ is power factor $(\approx 0.85), \eta$ is a mechanical efficiency $(\approx 0.95), \mathrm{I}_{2}$ and 
$I_{1}$ are line current strength (amperes) for extruder with and without load.

The dimensions mean of GFP strand was measured to calculate Er by;

$$
\mathrm{Er}=\frac{\text { Avg. of GFP strand dimensions }(\text { width } \times \text { thickness })}{\text { Die hole dimentions }(\text { width } \times \text { thickness })} .
$$

\section{E. Cooking properties}

About $100 \mathrm{~g}$ of GFP from each sample was separately cooked in one litre of boiling water until the optimum cooking time (OCT). The OCT was determined using Approved Method 66-50 [20]. Two pieces of GFP were withdrawn every $20 \mathrm{Sec}$ and squeezed gently between two glass plates until seeing the disappearance of the white central core of noodle. Then, it was rinsed in cold water and drained in a sieve at room temperature for $15 \mathrm{~min}$. Thereafter, cooking water was collected and evaporated at $115^{\circ} \mathrm{C}$ for $24 \mathrm{~h}$ to determine solid lost.

The volume of fresh and cooked noodle was determined by liquid (petroleum naphtha) displacement method. Cooked yield (CY) was calculated by;

$$
\mathrm{CY}(\%)=\frac{\mathrm{W}_{2}-\mathrm{W}_{1}}{\mathrm{~W}_{1}} \times 100,
$$

Where, $\mathrm{W}_{1}$ is a weight of uncooked noodle and $\mathrm{W}_{2}$ is a weight of cooked drained noodle at OCT [20]. Swelling (Sw) was determined by;

$\mathrm{Sw}(\%)=\frac{\mathrm{V}_{2}-\mathrm{V}_{1}}{\mathrm{~V}_{1}} \times 100$, where, $\mathrm{V}_{1}$ is a volume of uncooked noodle and $\mathrm{V}_{2}$ is a volume of cooked drained noodle at OCT. Cooking loss (CL) was calculated by

$$
\mathrm{CL}(\%)=\frac{\text { Weight of drained water }}{\mathrm{W}_{1}} \times 100^{[20]}
$$

\section{F. Sensory evaluation}

Appearance, colour, taste, mouth feel (tenderness) and overall acceptability were considered for sensory evaluation. The samples were subjected to scoring to evaluate their attributes on a comparative basis. Sensory testing was done at room temperature. Ten trained panellists were selected from Food Technology Research Institute (FTRI) to evaluate the sensory attributes. For these tests, GFP samples were cooked at OCT and then drained for $2 \mathrm{~min}$. The samples were coded and served at the same time. A five-point hedonic scale, Excellent (5), Good (4), Regular (3), Poor (2) and Unacceptable (1) was used.

\section{RESULTS AND DISCUSSIONS}

Specific mechanical energy (SME) measured energy consumption by extruder to produce one kilogram of GFP. The SME values ranged from 0.08 to $0.5 \mathrm{kWhkg}^{-1}$ (Fig. 3). These values are larger than those mentioned by Wójtowiez and Mościcki [17] (0.07 to 0.13) during wheat starch extrusion - cooking. The difference between these results maybe due to use of a lower temperature for wheat starch gelatinization [21].

The minimum and maximum values of SME were obtained at screw rotation speed (N) $10 \mathrm{rpm}$ with $40{ }^{\circ} \mathrm{C}$ and $50 \mathrm{rpm}$ with $115^{\circ} \mathrm{C}$. The lowest value of SME, which refers to the weak dough properties was obtained as a result of decline both extrusion rate and mechanical energy required to extrude. This caused by decreases in both of dough viscosity and friction between the dough and interior barrel surface (corn flour lipid reduces the friction between them). The critical level of friction was required to encourage the suitable movement of dough along the screw [22]. The SME transferred to the product was increased nearly from 0.05 to 0.13 by increasing $\mathrm{N}$ from 10 to $50 \mathrm{rpm}$ and BT from 40 to $115{ }^{\circ} \mathrm{C}$. These increases are due to energy added by heat energy which is generated along the screw like shearing, kinetic energy (created in the space between screw and barrel) and heater energy [23].

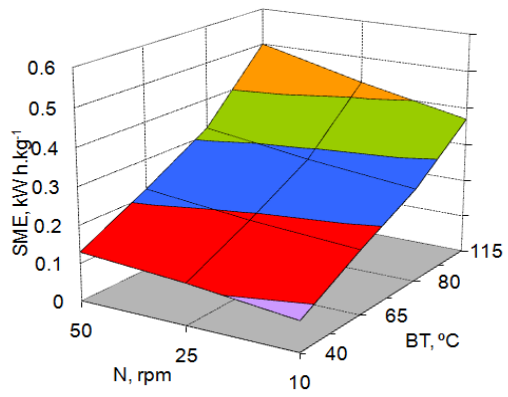

Fig.3: Effects of processing variables on specific mechanical energy (SME).

The expansion ratio (Er) of tagliatelle pasta ranged from 1 to 1.7 (Fig. 4). The values of extrusion variables were obtained lesser than those reported by Agama-Acevedo et al., [24], for producing pasta from unripe banana flour. Shear rate was increased by increasing $\mathrm{N}$, extrusion temperature and expansion degree. Also, the increases of BT leads to create a high vapour pressure in the dough that's lead to greater expansion. These effects were in agreement with those of Fang and Hanna [14] and Wójtowicz [5]. The values of $\mathrm{N}$ were given a non-significant effect under 40 and $65{ }^{\circ} \mathrm{C}$, and significant effect under 80 and $115^{\circ} \mathrm{C}$ of $\mathrm{BT}$ at $\mathrm{P}<0.05$. On the other hand, the BT had more significant effects on $\mathrm{Er}$ under the same value of $\mathrm{N}$. Moreover, the results were indicated to a positive correlation between $\mathrm{Er}$ and $\mathrm{BT}$ at different $\mathrm{N}$. Where, $\mathrm{Er} \approx 0.7778 \mathrm{e}^{0.0057} \mathrm{BT} \approx 0.0087 \mathrm{BT}+$ $0.6354 \approx 0.0091 \mathrm{BT}+0.6523$, with $\mathrm{R} \approx 0.99,0.98$, and 0.99 at $\mathrm{N} \approx 10,25$ and $50 \mathrm{rpm}$, respectively (data not shown). Eventually, the obtained results show a roughly linear positive correlation between SME and Er. Rather, Er $\approx 1.8675 \mathrm{SME}+0.8037$, with $\mathrm{R} \approx 0.99$ (Data not shown).

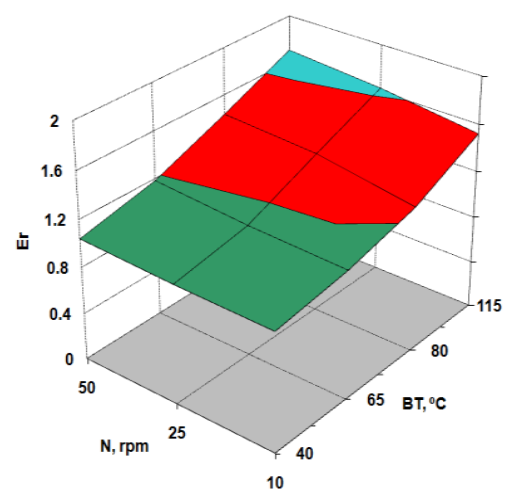

Fig.4. Effects of processing variables on the expansion ratio (Er).

The relationship between OCT and processing variables $\mathrm{N}$ and BT was demonstrated in Fig.5. Generally, pasta made by extruder showed shorter OCT than other manufactures processing due to higher temperatures in the extrusion process and thus starch gelatinization [25]. The maximum 
value of OCT (4.34 min) was obtained at $\mathrm{BT}=105{ }^{\circ} \mathrm{C}$ with $\mathrm{N}=50 \mathrm{rpm}$. This value is less than the one mentioned by Kosović et al. [25] and Manthey et al. [22] (6.2 \pm 0.1 and $10.2 \mathrm{~min})$ for pasta made from durum semolina. On the other hand, Iancu et al. [26] found OCT $=3 \pm 0.5 \mathrm{~min}$ for GFP. This fact was compatible with $(\mathrm{OTC}=3.3 \mathrm{~min}) \mathrm{BT}=$ $80{ }^{\circ} \mathrm{C}$ and $\mathrm{N}=25 \mathrm{rpm}$. In this respect, $\mathrm{Oh}$ et al. [27] has been mentioned the increases in flour protein correlated with increase cooking time. So, these results may be returned to a decrease in protein percentage (12\%) of GFP from corn flour [28]. Beside, coagulation of proteins may be occurred with absence of gluten network (low gluten content) and protein not enough to cause a reaction to boil a GFP. Furthermore, overall high expansion ratio lead to a weak on gluten network, seems to facilitate and faster penetration of water diffusion through the spaghetti matrix. All these facts lead to reduce the time that water needs to reach the pasta centre during the cooking process, which resulted in short cooking time [29], [30].

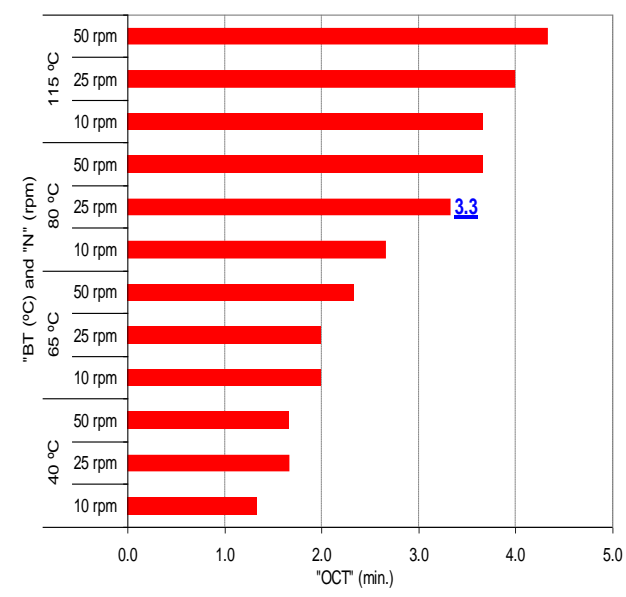

Fig.5. The relation between optimum cooking time (OCT) and processing variables BT and N.

Results which derived from data revealed that, OCT had a direct proportion with $\mathrm{BT}$ and $\mathrm{N}$. Wherever, by increase a BT from 40 to $115^{\circ} \mathrm{C}$ the OCT increases about 2, 2.34, and $2.67 \mathrm{~min}$ at 10,25 and $50 \mathrm{rpm}$ of $\mathrm{N}$, respectively. Meanwhile, the OCT increases about $0.34 \mathrm{~min}$ only by increasing $\mathrm{N}$ from 10 to $50 \mathrm{rpm}$ at 40,65 and $77^{\circ} \mathrm{C}$ of BT and about $1 \mathrm{~min}$ at $115^{\circ} \mathrm{C}$ of $\mathrm{BT}$. These results are in agreement with Wang et al. [31], who noted that, cooking time increase with increasing BT or N. Otherwise, its led to increasing dough temperature and lessen dough moisture content. Subsequently, a small water amount in the pregelatinized flour reduces cooking time [32].

The highest $(212 \%)$ and lowest $(165 \%)$ values of cooked yield (CY) were obtained at $115^{\circ} \mathrm{C}$ with $50 \mathrm{rpm}$ and $40{ }^{\circ} \mathrm{C}$ with $10 \mathrm{rpm}$. Maximum value of $\mathrm{CY}$ was more than that obtained by Pamela et al. [33] (186.13\%) for durum wheat semolina. This consequence may be due to strongly form of protein network that thwarts water diffuses into the starch granules. So, spaghetti with higher protein content absorbs water less than spaghetti with using corn flour as a raw material [21], [34]. There was a direct proportion between both (BT \& N) and CY. Results which derived from Table (I), show that, CY increase about $19,17,21$ and $14 \%$ at 40 , 65,80 and $115{ }^{\circ} \mathrm{C}$ by increasing $\mathrm{N}$ from 10 to $50 \mathrm{rpm}$, respectively. Meanwhile, it was increased from 165 to 198 ,
172 to 203 and 184 to $212 \%$ at 10,25 and $50 \mathrm{rpm}$ by increase BT from 40 to $115^{\circ} \mathrm{C}$, respectively. Therefore, both $\mathrm{BT}$ and $\mathrm{N}$ have significant effects $(\mathrm{P}>0.05)$ on $\mathrm{CY}$. These results have been dissimilar to those reported by Wang et al. [31]. Whereas, CY has been an inverse proportion with $\mathrm{N}$. The increases of $\mathrm{N}$ due to increase in shear, which led to modify the structure of starch. As well as, BT had little effect on CY.

Swelling ( $\mathrm{Sw}$ ) has been a direct proportion with processing variables (Table I). Similar observations were found as Kim and Wiesenborn [35]. Moreover, Abecassis et al. [36] pointed out that $\mathrm{N}$ and $\mathrm{BT}$ have been a beneficial effect on increasing Sw at extrusion screw. Also, it has been positive correlations with $\mathrm{N}$ and $\mathrm{T}$ at all treatments. There was a positive power correlation among $\mathrm{Sw}$ and BT with 10 and $50 \mathrm{rpm}$. As well as $\mathrm{N}$ with $40{ }^{\circ} \mathrm{C}$. Moreover, there were positive logarithmic correlations between $\mathrm{Sw}$ and other processing variables. As well as, previous relations were fitted to the following equations;

$\begin{array}{lll}\mathrm{Sw} \approx 41.426(\mathrm{BT})^{0.3379} & \text { at } 10 \mathrm{rpm} & \mathrm{R}^{2}=0.9769 \\ \mathrm{Sw} \approx 63.871 \mathrm{Ln}(\mathrm{BT})-73.794 & \text { at } 25 \mathrm{rpm} & \mathrm{R}^{2}=0.9896 \\ \mathrm{Sw} \approx 71.231(\mathrm{BT})^{0.2553} & \text { at } 50 \mathrm{rpm} & \mathrm{R}^{2}=0.9431 \\ \mathrm{Sw} \approx 104.45(\mathrm{~N}))^{0.1402} & \text { at } 40^{\circ} \mathrm{C} & \mathrm{R}^{2}=0.9912 \\ \mathrm{Sw} \approx 23.803 \mathrm{Ln}(\mathrm{N})+111.15 & \text { at } 65^{\circ} \mathrm{C} & \mathrm{R}^{2}=0.9899 \\ \mathrm{Sw} \approx 24.866 \mathrm{Ln}(\mathrm{N})+129.81 & \text { at } 80^{\circ} \mathrm{C} & \mathrm{R}^{2}=1 \\ \mathrm{Sw} \approx 18.978 \mathrm{Ln}(\mathrm{N})+162.99 & \text { at } 115^{\circ} \mathrm{C} & \mathrm{R}^{2}=0.9529\end{array}$

The maximum augmentation of $\mathrm{Sw}(66$ and $40 \%)$ was obtained at $25 \mathrm{rpm}$ with increasing BT from 40 to $115^{\circ} \mathrm{C}$ and at $80{ }^{\circ} \mathrm{C}$ with increasing $\mathrm{N}$ from 10 to $50 \mathrm{rpm}$. Furthermore, the results of Sw were affected significantly by both $\mathrm{T}$ and $\mathrm{N}(\mathrm{P}>0.05)$.

TABLE I: EFFECTS OF PROCESSING VARIABLES ON COOKING YIELD (CY) AND SWELLING (SW).

\begin{tabular}{l||cccccc}
\hline \hline \multicolumn{1}{l||}{} & \multicolumn{3}{c}{ Coking yield (CY), \% } & \multicolumn{3}{c}{ Swelling (Sw), \% } \\
\multicolumn{1}{l|}{ NT, rpm,${ }^{\circ} \mathrm{C}$} & 10 & 25 & 50 & 10 & 25 & 50 \\
\hline 40 & 165 & 172 & 184 & 145 & 162 & 182 \\
65 & 175 & 179 & 192 & 165 & 190 & 203 \\
80 & 183 & 196 & 204 & 187 & 210 & 227 \\
115 & 198 & 203 & 212 & 205 & 228 & 235 \\
\hline \hline
\end{tabular}

The results of cooking losses (CL) have been a direct and inverse proportion with $\mathrm{N}$ and BT (Fig. 6). The effects of extrusion variables on CL were similar to Mestres et al. [37] and Wang et al. [31]. On the other hand, the results obtained were differed considerably with Abecassis et al. [36]. Also, the $\mathrm{CL}$ was given a higher value $(22.7 \%)$ at $40{ }^{\circ} \mathrm{C}$ with 50 $\mathrm{rpm}$. Meanwhile, the lowest value $(12.4 \%)$ was recorded at $115{ }^{\circ} \mathrm{C}$ with $10 \mathrm{rpm}$. However, CL for all treatments was given a higher significantly than those mentioned by Lu et al. [38] for noodles of wheat. On the other hand, it was more less than declared by Mestres et al. [37] that CL about 70\% of extruded maize flour pasta. This increase might be due to soluble dietary fibre, where corn contains about $19.3 \%$ fibre with $6.53 \%$ soluble fibre [1], and weak starch-gluten network [22], [35]. The correlations of cooking properties OCT, CY, Sw and CL could be summarized as following equations;

$\mathrm{CY} \approx 13.197(\mathrm{OCT})+152.66$

$\mathrm{Sw} \approx 66.36 \mathrm{Ln}(\mathrm{OCT})+133.1 \approx 360.35 \mathrm{Ln}(\mathrm{CY})-1692.2$

$\mathrm{CL} \approx-5.7292 \operatorname{Ln}(\mathrm{OCT})+22.787 \approx 56.032 \mathrm{e}^{-0.0063}(\mathrm{CY})$ 
$\mathrm{CL} \approx-0.0516(\mathrm{Sw})+27.509$

From the results SME has been a positive power correlation with all cooking properties except CL. Whereas, it has been a negative linear correlation with cooking losses CL. Where, $\mathrm{SME} \approx 0.0608(\mathrm{OCT})^{1.5984}$

$\mathrm{SME} \approx 8 \times 10^{-17}(\mathrm{CY})^{6.7878}$

$\mathrm{SME} \approx 2 \times 10^{-9}(\mathrm{Sw})^{3.494} \approx-0.0306(\mathrm{CL})+0.7877,($ Data not shown).

On the other hand, Er values have been an exponential correlation with cooking properties. It was given a positive correlation with OCT, CY and Sw and a negative correlation with CL. $\mathrm{Er} \approx 0.766 \mathrm{e}^{0.182}$ (OCT)
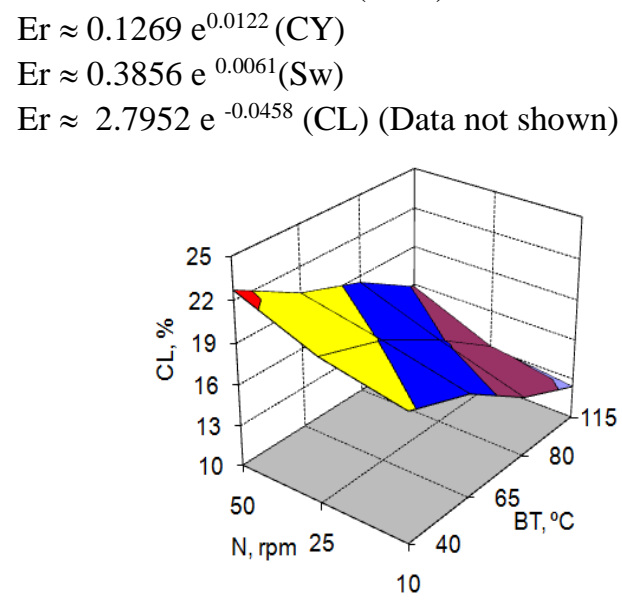

Fig. 6. Effects of processing variables on cooking losses (CL).

Sensory attributes of GFP as appearance, colour, taste, mouth feel and overall acceptability were represented graphically as given in Fig.7. Sensory evaluation graph revealed that highest ranking scores in appearance and colour $(4.6 \pm 0.2$ and $4.8 \pm 0.09)$ were found at $80{ }^{\circ} \mathrm{C}$ with $25 \mathrm{rpm}$. It was decreased dramatically to ruffle appearance and undesirable dull brown $(1.4 \pm 0.44$ and $1.7 \pm 0.28)$ at $115^{\circ} \mathrm{C}$ with 50rpm. Meanwhile, there were a slight improvement in taste and mouth feel from (2.5 to 4.5$)$ and (1.5 to 4.8) at (80 $\left.{ }^{\circ} \mathrm{C}-10 \mathrm{rpm}\right)$ and $\left(115^{\circ} \mathrm{C}-50 \mathrm{rpm}\right)$. On the other hand, the lowest score of all sensory attributes; appearance (1.4), taste (2.5) and mouth feel (1.5) except colour was obtained at $40^{\circ} \mathrm{C}$ with $10 \mathrm{rpm}$. The lowest score of colour (1.7) was found at $115^{\circ} \mathrm{C}$ with $50 \mathrm{rpm}$. It is clearly seen that, all attributes were affected significantly by BT. While, only colour was affected significantly by $\mathrm{N}$ on attributes. The GFP colour was transformed slightly from light yellow at $65{ }^{\circ} \mathrm{C}$ with 10 $\mathrm{rpm}$ to pleasant yellow at $80{ }^{\circ} \mathrm{C}$ with $25 \mathrm{rpm}$. It was developed and decreased dramatically to undesirable dull brown at $80{ }^{\circ} \mathrm{C}$ with $25 \mathrm{rpm}$ till $115^{\circ} \mathrm{C}$ with $50 \mathrm{rpm}$. These results maybe return to a high carotene in corn, which oxidized by some substances at high temperature. So, high temperature has a negative effect on pasta colour. As well as, the increase of BT or N leads to change the colour from pleasant yellow to dull brown. These results consent and in harmony with Abecassis et al. [36]; Fang and Hanna [14]; Iancu et al. [26]; Kahlon et al. [1] and Kosović et al. [25].

The taste results of GFP return to the corn flour flavour and defined as "al dente" [34, 13]. The results highlighted that maximum value of overall acceptability $(4.4 \pm 0.3)$ was obtained at $\mathrm{N}=25 \mathrm{rpm}$ with $\mathrm{BT}=80^{\circ} \mathrm{C}$. It was in the range ( $\mathrm{N}$ of $22-25 \mathrm{rpm}$ ) recommended by DeFreacisci [39] for extruder operators. This behaviour ascribed to GFP dough demand some heat to knead by extruder, which created by screw shear to malleable enough and squeeze through die.
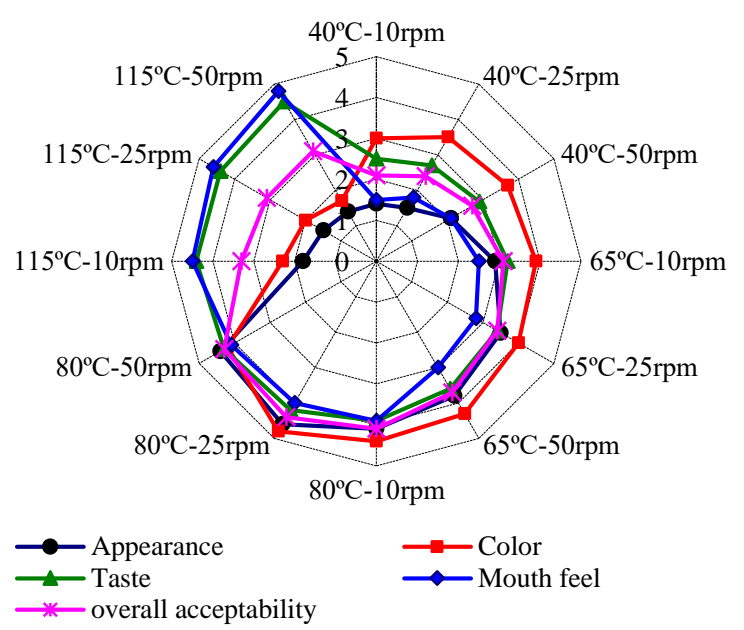

Fig.7. Relation between processing variables behaviour and sensory evaluation of corn noodle.

\section{CONCLUSION}

Electric heating system fixed on an extruder barrel to produce GFP from corn flour. The best sensory attributes of GFP produced at $80{ }^{\circ} \mathrm{C}$ and $25 \mathrm{rpm}$, with $\mathrm{SME}=0.28$ $\mathrm{kWhkg}^{-1}, \mathrm{Er}=1.38, \mathrm{OCT}=3.3 \mathrm{~min}, \mathrm{CY}=196 \%, \mathrm{Sw}=210 \%$ and $\mathrm{CL}=16.3 \%$. All parameters have a direct proportion with processing variables $\mathrm{N}$ and $\mathrm{BT}$, except CL with BT. Further, cooking properties could be predicted from SME value using the following equation; $\mathrm{SME} \approx 1.8675(\mathrm{Er})+$ $0.8037 \approx 0.0608(\mathrm{OCT})^{1.5984} \approx 8 \times 10^{-17}(\mathrm{CY})^{6.7878} \approx 2 \times 10^{-9}$ $(\mathrm{Sw})^{3.494} \approx-0.0306(\mathrm{CL})+0.7877$.

\section{REFERENCES}

[1] T. S. Kahlon, R.R. Milczarek, and M.M. Chiu, "Whole grain gluten - free egg- free pastas", Cereal foods world, 58, pp. 4-7, 2013.

[2] M. Mastromatteo, S. Chillo, M. Iannetti, V. Civica, and M. A. Del Nobile, "Formulation optimization of gluten-free functional spaghetti based on quinoa, maize and soy flours", International journal of Food Science \& Technology, 46, pp. 1201-1208, 2011.

[3] IPO (2013). International pasta organization. The world pasta industry status report. IPO, www.Internationalpasta.org .

[4] M. Niewinski, "Advances in celiac disease and gluten-free diet", Journal of the American Dietetic Association, 108, pp. 661-672, 2008.

[5] A. Wójtowiez, "Influence of process conditions on selected texture properties of precooked buckwheat pasta", TEKA commission of motorization and energetics in agriculture, 12 pp. 315-322, 2012.

[6] C. Heredia, F. Castro, and J.Palma, "Adult celiac disease", Revista Médica de Chile, 135, pp. 1186-1194, 2007.

[7] X. Jun, and N. Michael, 'Thermal properties of batter systems formulated by combinations of different flours", LWT-Food Science and Technology, 40, pp. 1459-1465, 2007.

[8] M. X. Liu, and P. Lu, "Distribution of Vitamin E content and its correlation with agronomic traits and catotenoids content in foxtail millet varieties in China", Acta Agronomica Sci., 39, pp. 398-408, 2013.

[9] B. S. Yadav, R. B. Yadav, and M. Kumar, 'Suitability of pigeon pea and rice starches and their blends for noodle making", LWT-Food Science and Technology, 44, pp. 1415-1421, 2011.

[10] L. Liu, T.J. Herald, D. Wang, J.D. Wilson, S.R. Bean, and F.M Aramouni, "Characterization of sorghum grain and evaluation of sorghum flour in a Chinese egg noodle system", Journal of Cereal Science, 55, pp. 31-36, 2012.

[11] L. Padalino, M. Mastromatteo, L. Lecce, F. Cozzolini, and M.A. Del Nobile, "Manufacture and characterization of gluten-free spaghetti 
enriched with vegetable flour", Journal of Cereal Science, 57, pp. 333-342, 2013.

[12] F. A. Fiorda, J.R. Soares, F. Da Silva, M. V. E. Grosmann, and L. R. F. Souto, "Microstracture, texture and colour of gluten-free pasta made with amaranth flour, cassava starch and cassva bagasse". LWTFood Science and Technology, 54, pp. 132-138, 2013.

[13] S. Sabbatini, M. de la. Torre, H. Sánchez, C. Osella, "Design of a premix for making gluten free noodles", International Journal of Nutrition and Food Sciences, 3, pp. 488-492, 2014.

[14] Q. Fang, and M.A. Hanna, "Extrusion systems: Design. Encyclopedia of agricultural, food, and biological engineering", Second edition, ed. Dennis R. Heldman \&Carmen I. Moraru., 1, pp. 470-473, 2010.

[15] L. Mościcki, and D.J. Van Zuilichem, "Extrusion-Cooking and Related Technique Extrusion-Cooking Techniques:Applications", Theory and Sustainability. Edited by Leszek Moscicki Copyright- 2011 Wiley-VCH Verlag GmbH \&Co. KGaA, Weinheim, 2011.

[16] A. Ficarella, M. Milanese, D. Laforgia, "Numerical study of extrusion process in cereals production: Part I. Fluid-dynamic analysis of extrusion system", 73, pp. 103-111, 2004.

[17] A. Wójtowicz, and L. Mościcki, "Energy consumption during extrusion-cooking of precooked pasta", TEKA Commission of Motorization and Power Industry in Agriculture, 8 pp. 311-318, 2008 .

[18] G.J. Rokey, "Single screw extruder". In extruders in food applications; Riaz, M.N., Ed; Technomic Publishing Co.: Lancaster, PA., pp. 30-31, 2000.

[19] P. Fellows, "Food processing technology": principles and practice, (2nd ed.), CRC Press, Boca Raton, United States of America, 2000.

[20] AACC. American Association of Cereal Chemists. "Approved Methods of Analysis", $11^{\text {th }}$ ed. The Association: St. Paul, MN., USA. 2010 .

[21] E. I. Yousif, M. G. E. Gadallah, and A. M. Sorour, "Physicochemical and rheological properties of modified corn starches and its effect on noodle quality", Annals of Agricultural Science, 57, pp. 1927, 2012.

[22] F. A. Manthey, S.R. Yalla, T. J. Dick, and M. Badaruddin, "Extrusion properties and cooking quality of spaghetti containing buckwheat bran flour", Cereal Chemistry, 81, pp. 232 -236, 2004.

[23] L.P. Janssen, L. Mościcki, and M. Mitrus, "Energy aspects in food extrusion - cooking”, International Agrophysics, 16, pp. 191-195, 2002.

[24] E. Agama-Acevedo, J. J. Islas-Hernandez, P. Osorio-Díaz, R. Rendón- Villalobos, R. G. Utrilla-Coello, O. Angulo, and L.A. Bello-Pérez, "Pasta with unripe banana flour: Physical, texture, and preference study", Journal of Food Science, 74, pp. 263-267, 2009.

[25] I. Kosović, M. Jukić, A. Jozinović, D. Aćkar, and D.K. Komlenić, 'Influence of chestnut flour addition on quality characteristics of pasta made on extruder and minipress". Czech.J. Food Sci., 34, pp. $166-172,2016$
[26] A. Iancu, D. Tucu, and G. Damacus, "Studies on the behavior of gluten -free pasta to boiling", Scientific Bulletin. Series. D. Inginerie Mechanicâ. Politehnica Univ., Timişora, România- Associted, 2015.

[27] N. H. Oh, P. A. Seib, A. B. Ward, and C. W. Deyoe, "Noodles, IV. Influence of flour protein, extraction rate, particle size, and starch damage on the quality characteristics of dry noodles", Cereal Chem., 62, pp. 441-446, 1985.

[28] C. Semasaka, X. Kong, and Y. Hua, "Optimization of extrusion on blend flour composed of corn, millet and soybean", Pakistan Journal of Nutrition, 9, pp. 291-297, 2010.

[29] N. Aravind, M. Sissons, N. Egan, and C. "Fellows, Effect of insoluble dietary fibre addition on technological, sensory, and structural properties of durum wheat spaghetti", Food Chemistery, 130, pp. 299-309, 2012.

[30] G. Kaur, S. Sharma, and H.P.S. Nag, 'Enrichment of pasta with different plant proteins", Journal of Food Science and Technology, 50, pp. 1000-1005, 2013.

[31] N. Wang, P.R. Bhirud, F.W. Sosulski, and R.T. Tyler, "Pasta-Like Product from Pea Flour by Twin-Screw Extrusion", Journal of Food Science, 64, pp. 671-678, 1999.

[32] U. Purwandari, A.Khoiri, M. Muchlis, B. Noriandita, N.F. Zeni, N. Lisdayana, and E. Fauziyah, "Textural, cooking quality, and sensory evaluation of gluten-free noodle made from breadfruit, konjac, or pumpkin flour", International Food Research Journal, 21, pp. 1623$1627,2014$.

[33] C. F. Pamela, J. J. Berriosb, J. Pan, E. Agama-Acevedoa, A. Monsalve-Gonzálezc, and L. A. Bello-Péreza, "Gluten-free spaghetti with unripe plantain, chickpea and maize: physicochemical, texture and sensory properties". CyTA-Journal of Food, 13, pp. 159-166, 2015 .

[34] D. Y. Ma, J. hang, X. Y. Lou, X. N. Wang, C. Y. Wang, and T. C. Guo, "Color, cooking properties and texture of yellow alkaline noodles enriched with millet and corn flour", International Food Research Journal, 21, pp. 1187-1192, 2014.

[35] Y.S. Kim, and D.P. Wiesenborn, "Starch noodle quality as related to potato genotypes", J. Food Sci., 61, pp. 248-252, 1996.

[36] J. Abecassis, R. Abbou, M. Chaueand, M.H. Morel, and P. Vernoux, "Influence of extrusion conditions on extrusion speed, temperature, and pressure in the extruder and pasta quality", Cereal Chem., 71, pp. 247-253, 1994.

[37] C. Mestres, P. Colonna, M.C. Alexandre, and F. Matencio, "Comparison of various processes for making Maize pasta", Journal of Cereal Science, 17, pp. 277-299, 1993,

[38] Q. Lu, S. Guo, and S. Zhang, "Effects of flour lipids on textural and cooking qualities of Chinese noodles", Food Research International, 42, pp. 226-230, 2009.

[39] L.J. DeFreacisci, "Extrusion screw speed and fit affecting pasta quality", Pasta institute of Technology, Technical series, Occasional paper 2, 2012. 